\title{
EVALUATION OF THE EFFECTIVENESS OF ONLINE COURSES BASED ON THE COMMUNITY OF INQUIRY MODEL
}

\author{
Dr. Denizer YILDIRIM \\ ORCID: 0000-0002-4534-8153 \\ Faculty of Open and Distance Education \\ Ankara University \\ Ankara, TURKEY \\ Dr. Suleyman Sadi SEFEROGLU \\ ORCID ID: orcid.org/0000-0002-5010-484X \\ Department of Computer Education and Instructional Technology \\ Hacettepe University \\ Ankara, TURKEY
}

Received: 08/09/2020 Accepted: 21/09/2020

\begin{abstract}
The purpose of the study, in order to improve the courses presented in online environments based on Community of Inquiry, is to investigate relations among the Community of Inquiry' presences (teaching, social and cognitive), learners' characteristics (e.g. gender, age, occupational status, and the type of registered program), "e-readiness and expectations", and satisfaction by using the structural equation model. The study group consisted of 714 students enrolled in distance education programs. Three data collection tools were used to collect data. The findings revealed that "the presence of the students was at a moderate level, teaching and social presence had a significant positive effect of on cognitive presence, the level of presence did not vary based on the variables of demographic and discipline, the e-presence and expectation levels had a low impact on presence levels, and the level of presence had a significantly high impact on satisfaction." The findings also indicated that the online courses examined in this study were found to be sufficient by students in forming a community of inquiry. However, it also revealed that certain aspects of the courses should be improved. Therefore, it could be concluded that there is a need for more social, more active and engaging learning activities that enable students to think critically in an online environment.
\end{abstract}

Keywords: Online learning, The Community of Inquiry, e-presence and expectation, satisfaction.

\section{INTRODUCTION}

Online and blended environments in higher education are rapidly growing thanks to the benefits of interactive technologies that improve active learning and offer students flexibility (Giering, 2013; Johnson, Adams Becker, Estrada, \& Freeman, 2014; Seaman, Allen, \& Seaman, 2018; Siemens, Gasevic, \& Dawson, 2015; Roscorla, 2012). Reports on e-learning state that more than 65\% of faculty support the use of Open Educational Resources (OER), such as eLearning courses, and more than $49 \%$ of learners had taken part in some form of eLearning activity in the last 12 months (Duffin, 2019; Statista, 2019). Therefore, inevitably, educational institutions should investigate pedagogical perspectives on the effectiveness of online or blended education in parallel with technological developments.

Some studies have investigated the effectiveness of online learning in the literature. Simsek (2012) addressed the dimensions of quality, educational effectiveness, financial efficiency, accessibility, teaching staff satisfaction and student satisfaction in distance education. Crowther, Keller, and Waddoups (2004) examined the effectiveness and nature of online courses by means of usability methods. They discussed the dimensions of benefit, learning, productivity, and satisfaction. Levy (2008) attempted to determine the critical value factors of online course activities based on the Cognitive Theory of Value (Ragowsky, Somers, \& Adams, 2005) to 
study the effectiveness of online learning programs. Hence, from the students' perspective, the following aspects are important in a course: (1) collaborative, social and passive, and corporate communication, (2) corporate learning, (3) support, and (4) written/informative activities. Liu (2012) evaluated the distance education system through student self-reporting on the following dimensions: (1) organizing and planning course, (2) communication, (3) faculty/student interaction, (4) homework, exams, and grading, (5) teaching methods and materials, (6) learning outcomes, (7) student effort and participation,(8) course difficulty, and (9) workload, and speed.

"International Association for K-12 Online Learning" (INACOL), in striving to enhance the quality of education and focusing on student-based approaches in this process, has set various standards on blended learning design (INACOL, 2011), outcome-based quality (INACOL, 2012) and skills of online teachers (INACOL, 2011). Apart from these studies, the Community of Inquiry on the design of online or blended learning is one of the pedagogical models on which many studies were based. It has been widely used as a guide for developing and evaluating online courses as well as for education faculty to teach online (Heilporn \& Lakhal, 2020; Nolan-Grant, 2019; Rubin, Fernandes, \& Avgerinou, 2013; Shea \& Bidjerano, 2012; Stenbom, 2018; Szeto, 2015). Further, The Community of Inquiry has been used effectively to examine learning experiences and to compare different learning environments in many contexts (Stenbom, 2018). The combined result of Stenbom's systematic review is that the Community of Inquiry Survey is a widely accepted tool for revealing learners' perceptions of learning experience, and its measurement invariance was tested for many variables (gender, age, ethnicity, discipline, online experience) (Dempsey \& Zhang, 2019). So, it is a guide for the design of courses (Akyol, Vaughan, \& Garrison, 2011; Swan, Day, Bogle, \& Matthews, 2014).

A Community of inquiry is defined as a group of people cooperatively engaging in critical discussion and reflection in order to develop personal meaning and affirm understanding in reciprocation (Garrison, 2011). Cognitive, social, and teaching presence components at a high level online learning environment are necessary for an effective community of inquiry (Garrison, Anderson, \& Archer, 2000). Rockinson-Szapkiw, Wendt, Wighting, and Nisbet (2016) found that the students with high social presence, cognitive presence and teaching presence had higher grades. Additionally, perceived learning was positively correlated with students' grades. In community of inquiry model, deep learning is associated with cognitive presence level. Social and teaching presence levels explained at least $69 \%$ of the variance in cognitive presence (GutierrezSantiuste, Rodriguez-Sabiote, \& Gallego-Arrufat, 2015). The current study tested students' perceptions of presence as predicted in the literature. Therefore, it is possible to discuss which dimensions come into prominence for the design of the courses.

Cognitive presence derives from the epistemological, cultural and social expression of the particular content to support critical thinking (Anderson, 2008). If a community of inquiry emerges, along with other components, in an environment based on deep and meaningful learning, it enables a student to think critically and increases the level of cognitive presence (Kanuka \& Garrison, 2004). Cognitive presence has a positive effect on educational effectiveness (Lin, Hung, \& Lee, 2015). Social presence is the ability of students to present themselves as a real person and the degree of comfort and confidence needed to express their ideas by working collaboratively. It is an important indicator of emotional expression and persistence in online learning (Boston, Diaz, Gibson, Ice, Richardson, \& Swan, 2010). In an environment with low levels of social presence, students cannot share ideas, express disagreements, explain differences, and accept their peers' support. The purpose of social presence is to provide open communication and group cohesion (Garrison, 2011). Teaching presence is to design and implement learning processes to ensure cognitive and social presence (Anderson, 2003). Teaching and social presence have a significant impact on cognitive presence and teaching presence affects social presence (Garrison, Cleveland-Innes, \& Fung, 2010). An effective teaching presence in an online environment can be formed through accurate and timely use of group and independent study activities via synchronous and asynchronous interaction. 


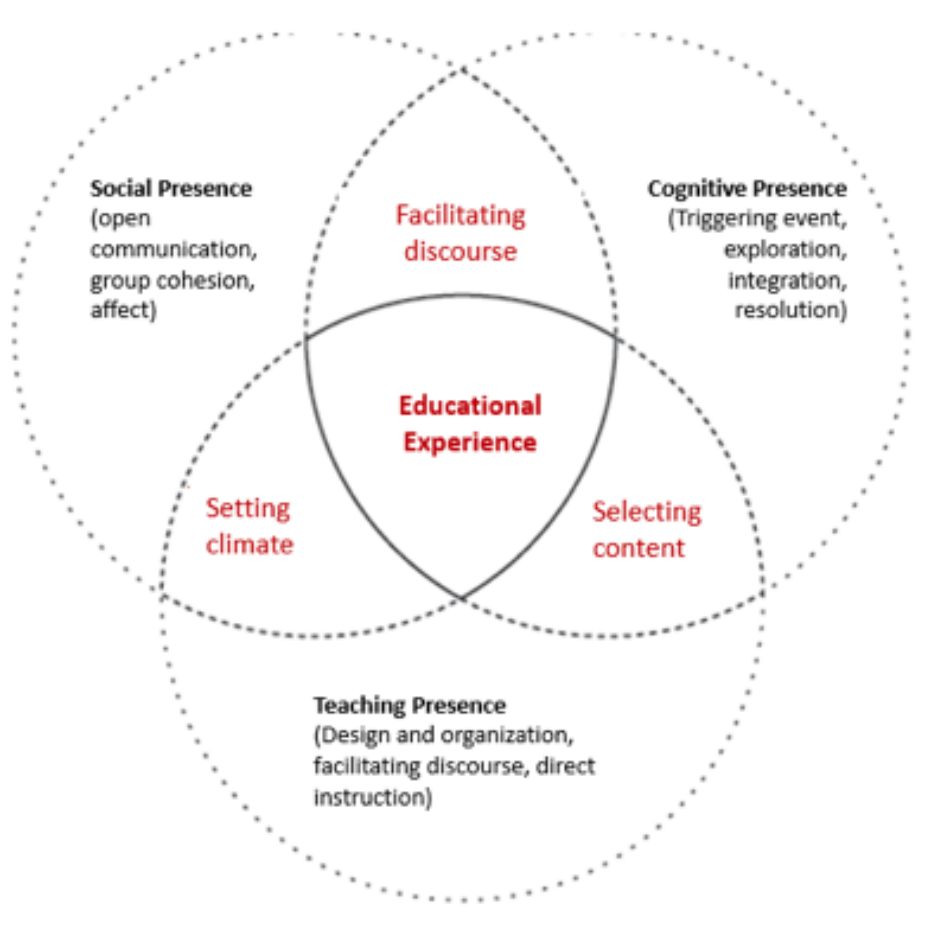

Figure 1. The Community of Inquiry Model (Garrison et al., 2000)

In the literature, the findings of some studies examining the Community of Inquiry and various variables (e.g. discipline, course duration, learner characteristics, satisfaction) revealed some indicators regarding the structuring of the courses (Arbaugh, 2013; Arbaugh, Bangert, \& Cleveland-Innes, 2010; Moreira et al., 2013; Stenbom, 2018). For example, learners' presences (teaching, social and cognitive) differ in terms of pure or applied disciplines and discipline affects the relationship between presences (Arbaugh, 2013). Stenbom's study comparing hard and soft disciplines found that the harder disciplines prioritized more teaching presence (Stenbom, 2018). Moreira et al. (2013) community feeling of polytechnic students is stronger than university students. Akyol et al. (2011) found differences in the three presences in short- and long-term courses. In terms of social presence, when a course was given for a shorter duration (6 weeks) than 13 weeks, students had a higher perception of group cohesion and lower effective communication. Besides, in terms of teaching presence, the perception of direct instruction is higher in the short course, while the perception of facilitating discourse is lower. In this context, it can be stated that the unique dynamics of each course have effects on the presences, so variables that address different dimensions (e.g. learner characteristics, e-presence and expectation, and satisfaction) need to be examined.

Learner characteristics can affect the development of teaching, social, and cognitive presence at different levels in the online learning environment (Akyol et al., 2011). Studies examining the Community of Inquiry and learner characteristics (e.g. gender, age) show inconsistent results. For example, Shea and Bidjerano (2009) found that gender, age, and academic level have a direct effect on only teaching presence. Akyol, Ice, Garrison, and Mitchell (2010) found age to be significant for presences. However, regardless of age, Decker and Beltran (2016) discovered that students have a feeling of belonging and can communicate comfortably in an online environment. Moreover, no significant relationship was found between students' ages and social presence (Horzum, 2015). Therefore, these results show that learner characteristics do not have the same effect on the Community of Inquiry in each course. One reason for the inconsistency may be that every learner comes to an online course with different e-presence and expectations that can affect learners' success (Hung, Chou, \& Chen, 2010; Ilgaz \& Gulbahar, 2015; Yeh et al., 2019). Learners contribute to the improvement of the community through their skills and knowledge while teachers design learning experiences and make necessary changes in building a community of inquiry. Therefore, the learners' level of readiness and expectations are significant from the viewpoint of the course teacher and/or the instructional designer with the role of designing activity. E-readiness and expectations, through which the important inputs of the online learning process are obtained, provides insight for the designer about the interventions that should be made in the phase of course design and implementation (Ilgaz \& Gulbahar, 2015). 
Another indicator of the effectiveness of online courses is learners' satisfaction (Eom \& Ashill, 2016; Yukselturk \& Yildirim, 2008). But, there are contradictory results in some studies in which Community of Inquiry presences and satisfaction are examined relationally. Students' satisfaction has high correlations with cognitive and social presence (Gutierrez-Santiuste, 2016) or only the cognitive presence (Choy \& Quek, 2016). In one study, satisfaction was predicted by each of the three presences (Giannousi \& Kioumourtzoglou, 2016) while another study found that social presence was not an indicator of satisfaction (Kucuk \& Richardson, 2019).

In summary, the effectiveness of online courses, which has been increasingly important in the last years, is a process full of challenges as each course has its dynamic. However, it is also necessary to discuss the effectiveness of online courses through theoretical models. Thus, the weaknesses of the course and the requirements for improvement are discovered. This study aims to evaluate the effectiveness of online learning courses based on Community of Inquiry Model. This model, providing insights for instructors on the strengths or weaknesses of a course (Dempsey \& Zhang, 2019; Lambert \& Fisher, 2013), can produce special practices that include facilitating elements of learning such as affective explanations, group discussions, research activities and course organization to create a more attractive and engaging course. While examining the effectiveness of online courses based on the Community of Inquiry, it can be stated that learner characteristics and satisfaction variables are still worth examining due to inconsistent results in the literature. On the other hand, no studies addressing e-readiness and expectation with Community of Inquiry have been found. In this context, the examination of the Community of Inquiry and various variables (such as learners' characteristics, "e-readiness and expectation" and satisfaction) with the Structural Equation Model may come up with suggestions to course design according to the student needs.

\section{PURPOSE OF THE STUDY}

The purpose of the study, in order to improve the courses presented in online environments based on Community of Inquiry, is to investigate relations among the Community of Inquiry' presences (teaching, social and cognitive), learners' characteristics (e.g. gender, age, occupational status, and the type of registered program), "e-readiness and expectations", and satisfaction by using SEM. In this context, answers are sought for the following research questions.

1. What are the levels of cognitive, social and teaching presence of the learners registered in online courses?

2. To what extent is cognitive presence predicted by the social and teaching presence in online courses?

3. Do the levels of cognitive, social and teaching presence of the students vary depending on gender, age, occupational status, and the type of registered program such as undergraduate and/or graduate degree?

4. What is the effect of the level of e-presence and expectations of the students on the perception of a community of inquiry?

5. What is the effect of the satisfaction levels of the students on their perception of a community of inquiry?

\section{METHOD}

In this study, the relationships among the three presences, demographics variables and different disciplines (the type of registered program), e-presence and expectation and satisfaction were investigated a structural equation modeling (SEM) approach.

\section{Participants}

This study examined 2100 students who were enrolled in distance education programs and attended online courses. The participants in the online scale comprised of 1178 students. After excluding invalid records, data obtained from 714 students were available for use. Of the participants, 69\% (493) were female and $46 \%$ of them (329) were enrolled in an undergraduate degree completion program. From the 691 students 
who stated their occupational status, 328 students (46\%) worked in some professions. Furthermore, the age of participants varied between 17-59 years old and the average age was 25,9 (see. Table 1).

Table 1. Distributions on the Demographic Characteristics of the Participants

\begin{tabular}{|c|c|c|c|c|c|c|c|c|c|c|c|c|c|c|c|}
\hline \multirow{3}{*}{ Programs } & \multicolumn{4}{|c|}{ Gender } & \multicolumn{4}{|c|}{ Marital Status } & \multicolumn{6}{|c|}{ Profession } & \multirow{3}{*}{$\begin{array}{l}\text { Ave. } \\
\text { of } \\
\text { Age }\end{array}$} \\
\hline & \multicolumn{2}{|l|}{ M } & \multicolumn{2}{|l|}{$\mathrm{F}$} & \multicolumn{2}{|l|}{ Yes } & \multicolumn{2}{|l|}{ No } & \multicolumn{2}{|c|}{ Unknown } & \multicolumn{2}{|l|}{ Yes } & \multicolumn{2}{|l|}{ No } & \\
\hline & $f$ & $\%$ & $f$ & $\%$ & $f$ & $\%$ & $f$ & $\%$ & $f$ & $\%$ & $f$ & $\%$ & $f$ & $\%$ & \\
\hline Judicial Services & 29 & 49,15 & 30 & 50,85 & 35 & 59,32 & 24 & 40,68 & 13 & 22,03 & 36 & 61,02 & 10 & 16,95 & 27,9 \\
\hline $\begin{array}{l}\text { Banking and } \\
\text { Insurance }\end{array}$ & 15 & 28,85 & 37 & 71,15 & 44 & 84,62 & 8 & 15,38 & 9 & 17,31 & 23 & 44,23 & 20 & 38,46 & 22,1 \\
\hline $\begin{array}{l}\text { Computer } \\
\text { Programming }\end{array}$ & 74 & 64,35 & 41 & 35,65 & 104 & 90,43 & 11 & 9,57 & 23 & 20,00 & 61 & 53,04 & 31 & 26,96 & 22,3 \\
\hline $\begin{array}{l}\text { Medical } \\
\text { Documentation }\end{array}$ & 24 & 19,35 & 100 & 80,65 & 68 & 54,84 & 56 & 45,16 & 24 & 19,35 & 53 & 42,74 & 47 & 37,90 & 25,2 \\
\hline $\begin{array}{l}\text { Tourism and Hotel } \\
\text { Management }\end{array}$ & 15 & 42,86 & 20 & 57,14 & 32 & 91,43 & 3 & 8,57 & 6 & 17,14 & 19 & 54,29 & 10 & 28,57 & 24,5 \\
\hline Divinity Diploma & 64 & 19,45 & 265 & 80,55 & 64 & 19,45 & 265 & 80,55 & 66 & 20,06 & 136 & 41,34 & 127 & 38,60 & 33,1 \\
\hline Total & 221 & 30,95 & 493 & 69,05 & 347 & 48,60 & 367 & 51,40 & 141 & 19,75 & 328 & 45,94 & 245 & 34,31 & 25,9 \\
\hline
\end{tabular}

\section{Data Collection and Analysis}

Four separate data collection tools were used to obtain the necessary data: the "Personal Information Form" prepared by the researchers, and the scales of "e-Presence and Expectation", "Community of Inquiry", and "e-Satisfaction." The Scale of e-Presence and Expectation was administered to the students in the first week of the fall semester, whereas the Scale of Community of Inquiry was applied in the 12th week, and the Scale of e-Satisfaction was applied in the 14 th week in an online environment.

This study utilized a confirmatory factor analysis for the reliability and validity of the scales. As a result, only Personal Characteristics dimension in e-Presence and Expectation was not confirmed. The load of two items out of four items was 0.5 and below. Validity and reliability results of the scales are shown in Table 2.

Table 2. Reliability Coefficients of the Scales in the Study

\begin{tabular}{|c|c|c|c|c|}
\hline \multirow{2}{*}{ Scales } & \multirow{2}{*}{ Factors } & \multirow{2}{*}{$\begin{array}{l}\text { Reliability } \\
\text { Coefficient (a) }\end{array}$} & \multicolumn{2}{|c|}{ Confirmatory Factor Analysis } \\
\hline & & & Item Load & Criterion \\
\hline \multirow{8}{*}{$\begin{array}{l}\text { e-Presence and } \\
\text { Expectation } \\
\text { (Gulbahar, 2012) }\end{array}$} & \multirow{4}{*}{ 1. Personal Characteristics } & \multirow{4}{*}{0.80} & Item 1: 0.38 & \multirow{5}{*}{$\begin{array}{l}\text { This dimension was } \\
\text { not included in the } \\
\text { analysis since the } \\
\text { load of two items out } \\
\text { of four items was } 0.5 \\
\text { and below. }\end{array}$} \\
\hline & & & Item2: 0.73 & \\
\hline & & & Item3: 0.40 & \\
\hline & & & Item4: 0.76 & \\
\hline & 2. Access to Technology & 0.77 & $0.58-0.85$ & \\
\hline & 3. Technical Skills & 0.79 & $0.75-0.92$ & \multirow{3}{*}{$\begin{array}{l}\text { RMSEA }=0.066 ; \mathrm{RMR}= \\
0.061 ; \mathrm{CFI}=0.98 ; \\
\mathrm{NFI}=0.98 ; \mathrm{NNFI}=0.98\end{array}$} \\
\hline & 4. Motivation and Attitude & 0.79 & $0.68-0.85$ & \\
\hline & 5. Factors Affecting Success & 0.77 & $0.62-0.85$ & \\
\hline \multirow{3}{*}{$\begin{array}{l}\text { The community of } \\
\text { Inquiry (Ozturk, 2012) }\end{array}$} & 1. Teaching Presence & 0.92 & $0.66-0.81$ & \multirow{3}{*}{$\begin{array}{l}\text { RMSEA }=0.061 ; \mathrm{RMR}= \\
0.021 ; \mathrm{CFI}=0.99 ; \mathrm{NFI} \\
=0.98 ; \mathrm{NNFI}=0.99\end{array}$} \\
\hline & 2. Social Presence & 0.88 & $0.67-0.81$ & \\
\hline & 3. Cognitive Presence & 0.75 & $0.71-0.85$ & \\
\hline \multirow{4}{*}{$\begin{array}{l}\text { e-Satisfaction } \\
\text { (Gulbahar,2012) }\end{array}$} & 1. Communication and Usability & 0.91 & $0.77-0.92$ & \multirow{4}{*}{$\begin{array}{l}\text { RMSEA }=0.078 ; \mathrm{RMR} \\
=0.043 ; \mathrm{CFI}=0.99 ; \\
\mathrm{NFI}=0.98 ; \mathrm{NNFI}= \\
0.99\end{array}$} \\
\hline & 2. Teaching Process & 0.93 & $0.76-0.87$ & \\
\hline & 3. Teaching Content & 0.94 & $0.88-0.92$ & \\
\hline & 4. Interaction and Evaluation & 0.96 & $0.81-0.91$ & \\
\hline
\end{tabular}


This study utilized a confirmatory factor analysis for the reliability and validity of the scales, descriptive statistics for the first research question and a structural equation model (SEM) for the other four research questions. The study further used SPSS 20.0 and LISREL 8 programs to perform the analyses. Structural equation model (SEM) is evaluated through some independent criteria. These criteria are called goodness of fit statistics and allow for the evaluation of the model's acceptability as a whole.

A difference between the covariance matrices (i.e., analyzed data and theoretical expectation) is expected in SEM studies. Accordingly, the first criterion that can be used is that the Chi-square value is not significant. However, as the size of the sample increases, the Chi-square value is generally found to be significant; for that reason, other goodness of fit statistics (GFI, AGFI, CFI, NFI, NNFI > .95; RMSEA, RMR, SRMR<.08) were also used (Hooper, Coughlan, \& Mullen, 2008; Simsek, 2007). Although the fit statistics are reported, there is no need for specifying every one of them. There is no consensus on which fit statistics method leads to a more valid result on the model's suitability in the literature. The most commonly used compliance indicators are CFI, GFI, NFI, NNFI, and RMSEA (McDonald \& Ho, 2002). Nevertheless, the GFI and AGFI may lead to misinterpretations on the model with latent variables (Hu \& Bentner, 1999). Thus, this study reported the indicators of CFI, NFI, NNFI, and RMSEA.

Structure of the Evaluated Online Courses

Regarding all the online courses in distance education programs available in the institutions, in which these practices were performed, the students can typically follow their courses on the Moodle Learning Management System where they communicate with instructors and access their exam results and announcements. In addition, the students can report questions and problems on the forums. They can follow the courses via online contents uploaded to the system (e.g., SCORM, fascicle, or video) and virtual classrooms. The courses in virtual classrooms were conducted by means of web conferencing at a date and time planned by the instructor. A commercial product (Adobe Connect) was used as the web conferencing system. Every practice in the virtual classrooms was recorded by the course teacher and accessed by the students who had not participated in the course. Further, the students can also access the camera recordings of the lecture provided by the instructor. The forums consisted of three different parts: (1) "student affairs forum" where the students can ask anything about student affairs, (2) "technical forum" where they can report on the technical issues they experience, and (3) "student forum" where they can communicate with each other.

\section{FINDINGS}

\section{The Levels of Cognitive, Social, and Teaching Presence of the Students registered in Online Courses}

In order to answer first research question, the average scores of the sub-dimensions were calculated. Table 3 presents the data distribution related to the question. The students opted for "I agree" on the statement that online courses create a feeling of presence. Accordingly, since the 4-point Likert-type scale comprised the agreement scale of "I strongly disagree," "I disagree," "I agree," and "I strongly agree," there is no definite distinction between the presence levels; for that reason, it can be stated that the students' presence was at a moderate level on a scale of four $\left(X_{\text {teaching }}=2,91, X_{\text {social }}=2,98, X_{\text {cognitive }}=2,96\right)$ (see. Table 3 ).

Table 3. Distributions of the Cognitive, Social and Teaching Presence Levels of the Students

\begin{tabular}{|c|c|c|c|c|c|c|c|}
\hline \multirow{2}{*}{ Sub Dimensions } & \multirow{2}{*}{ Mean } & \multicolumn{2}{|c|}{$\begin{array}{l}\text { 99\% Confidence } \\
\text { Interval }\end{array}$} & \multirow{2}{*}{ Variance } & \multirow{2}{*}{$\begin{array}{l}\text { Std. } \\
\text { Dev. }\end{array}$} & \multirow{2}{*}{ Skewness } & \multirow{2}{*}{ Kurtosis } \\
\hline & & Lower Limit & $\begin{array}{l}\text { Upper } \\
\text { Limit }\end{array}$ & & & & \\
\hline Personal Characteristics (pc) & 3,11 & 3,05 & 3,18 & 0,78 & 0,88 & 0,02 & $-0,06$ \\
\hline Access to Technology (at) & 3,95 & 3,88 & 4,03 & 1,03 & 1,01 & $-0,98$ & 0,36 \\
\hline Technical Skills (ts) & 4,01 & 3,94 & 4,08 & 0,97 & 0,98 & $-0,92$ & 0,10 \\
\hline Motivation and Attitude (mt) & 3,63 & 3,56 & 3,70 & 0,86 & 0,93 & $-0,42$ & $-0,15$ \\
\hline Factors Affecting Success (fas) & 4,19 & 4,13 & 4,26 & 0,75 & 0,87 & $-1,30$ & 1,61 \\
\hline
\end{tabular}




\begin{tabular}{lllllllll}
\hline Teaching Presence (t_pre) & 2,98 & 2,94 & 3,03 & 0,31 & 0,56 & $-0,36$ & 0,85 \\
\hline Social Presence (s_pre) & 2,91 & 2,87 & 2,95 & 0,35 & 0,60 & $-0,40$ & 0,74 \\
\hline Cognitive Presence (c_pre) & 2,96 & 2,92 & 3,00 & 0,32 & 0,57 & $-0,51$ & 1,20 & 0,37 \\
\hline Communication and Usability (cu) & 3,65 & 3,58 & 3,72 & 0,93 & 0,96 & $-0,72$ & 0,03 & 0,07 \\
\hline Teaching Process (tp) & 3,50 & 3,43 & 3,57 & 0,93 & 0,97 & $-0,54$ & 0,13 \\
\hline Teaching Content (tc) & 3,68 & 3,61 & 3,75 & 1,00 & 1,00 & $-0,65$ & $-0,42$ & $-0,20$ \\
\hline Interaction and Evaluation (ie) & 3,45 & 3,37 & 3,52 & 1,01 & 1,01 & $-0,42$ & \\
\hline
\end{tabular}

\section{The Extent Social and Teaching Presence Predict Cognitive Presence in Online Courses}

In order to answer second research question, the fit statistics of the structural equation model developed in the study were analyzed. It can be stated that the fit of the model was at an acceptable level (CFI=0.98, $\mathrm{NFI}=0.99, \mathrm{NNFI}=0.99, \mathrm{RMSEA}=0.061$ ). Figure 2 shows the established structural equation model.

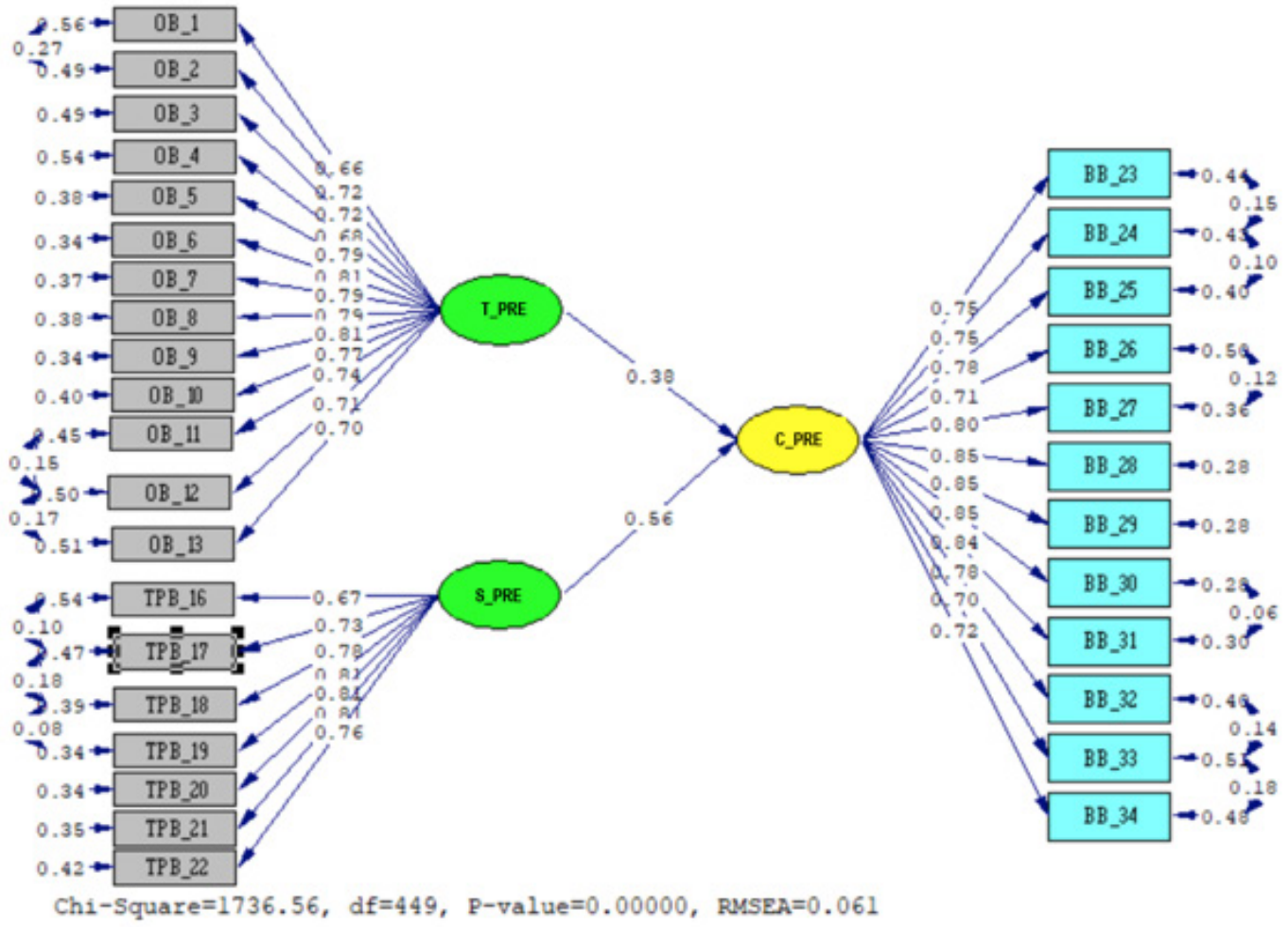

Figure 2. Structural equation modeling of the effects of social presence and teaching presence on cognitive presences.

By model, there is a significant positive effect of teaching and social presence on cognitive presence $\left(\mathrm{t}_{\mathrm{s} \_ \text {pre }}\right.$ $\left.=12.82, \beta_{s_{-} p r e}=0.56, t_{t_{-} p r e}=10.50, \beta_{t_{-} p r e}=0.14\right)$. The two variables $\left(\mathrm{R}_{s_{-} p r e}^{2}=0.314, \mathrm{R}_{t_{-} p r e}^{2}=0.144\right)$ together account for $45,8 \%$ of the total variance in cognitive presence (see. Table 4 ).

Table 4. The Effects of Social Presence and Teaching Presence on Cognitive Presence

\begin{tabular}{llll}
\hline Latent variables & Beta & $\mathrm{t}$ & $\mathrm{R} 2$ \\
\hline Social Presence (s_pre) & 0.56 & 12.82 & 0.314 \\
Teaching Presence (t_pre) & 0.38 & 10.50 & 0.144 \\
Total Variance & & & 0.458 \\
\hline
\end{tabular}




\section{The Analysis of the Levels of Cognitive, Social, and Teaching Presence of the Students Based on Various Variables}

In order to find answers to the third research question, the fit statistics of the structural equation model of this study were analyzed. It can be stated that the fit of the model was at an acceptable level (CFI=0.98, $\mathrm{NFI}=0.98, \mathrm{NNFI}=0.96, \mathrm{RMSEA}=0.67)$. The latent variables of the categorical variables, such as sex, marital status, occupational status, and the type of registered program, were formed by being multiplied by 1 value.

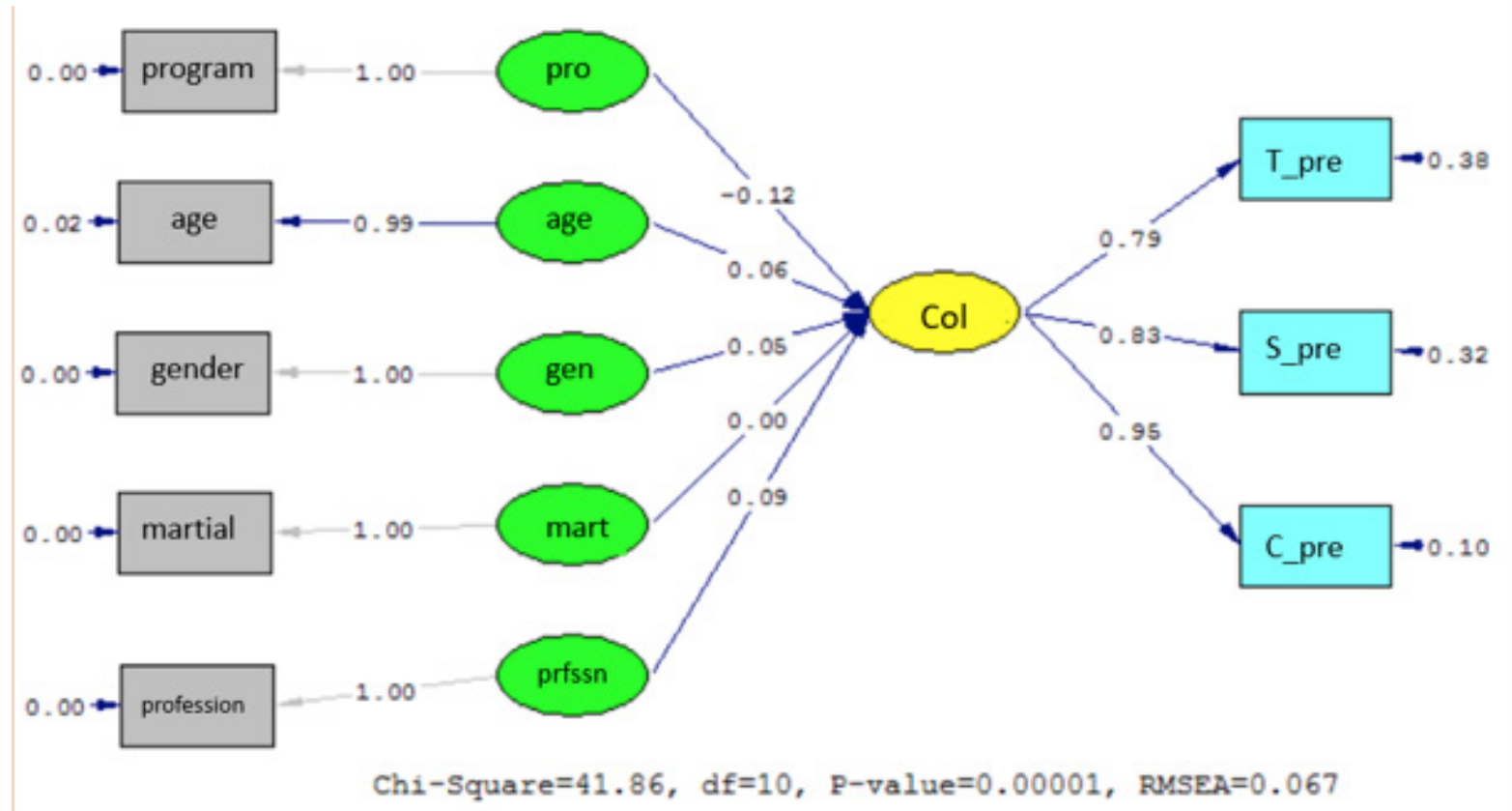

Figure 3. Structural equation modeling of the perception levels of the community of inquiry of the students according to various variables.

As seen in Figure 3, the effect size of the variables of gender, marital status, occupational status, program, and age on the perception level of the community of inquiry was very low $\left(\beta_{\text {gender }}=0.05, \beta_{\text {martial }}=0.00\right.$, $\beta_{\text {profession }}=0.09^{*}, \beta_{\text {age }}=0.06, \beta_{\text {program }}=-0.12^{*}$ ). The students' perception on the community of inquiry did not vary significantly depending on age, gender, martial $\left(\mathrm{t}_{\mathrm{age}}=1.01, \mathrm{t}_{\text {gender }}=1.07, \mathrm{t}_{\text {martial }}=0.08\right)$. The students' perception levels on the community of inquiry varied significantly depending on program and profession status $\left(\mathrm{t}_{\text {profession }}=2.25, \mathrm{t}_{\text {program }}=-2.41\right)$. Furthermore, the effect size of each presence level of the students on the community of inquiry was significant and high $\left(_{\text {tc_pre }}=31.73, \beta_{\text {c_pre }}=0.95, t_{\text {s_ppre }}=25.83\right.$, $\left.\beta_{\text {s_pre }}=0.83, \mathrm{t}_{\mathrm{t} \_ \text {pre }}=24.27, \beta_{\mathrm{t} \_ \text {pre }}=0.79\right)$.

\section{Effect of the Level of e-Presence and Expectations of the Students on Social, Cognitive, and Teaching Presence}

In order to answer the fourth research question, the fit statistics of the structural equation model of this study were analyzed. It can be stated that the fit of the model was at an acceptable level (NNFI $=0.97, \mathrm{CFI}=0.97$, $\mathrm{NFI}=0.96$, RMSEA=0.07).

Since the relevant items in the personal characteristics dimension in the e-presence and expectation scale in the structural equation model were not loaded above 0.5 , this dimension was not included in the study. In the subsequent analysis, it was found that the effect size of the levels of e-presence and students' expectations on the presence levels were low. Figure 4 demonstrates the effect sizes for the sub-dimensions. 


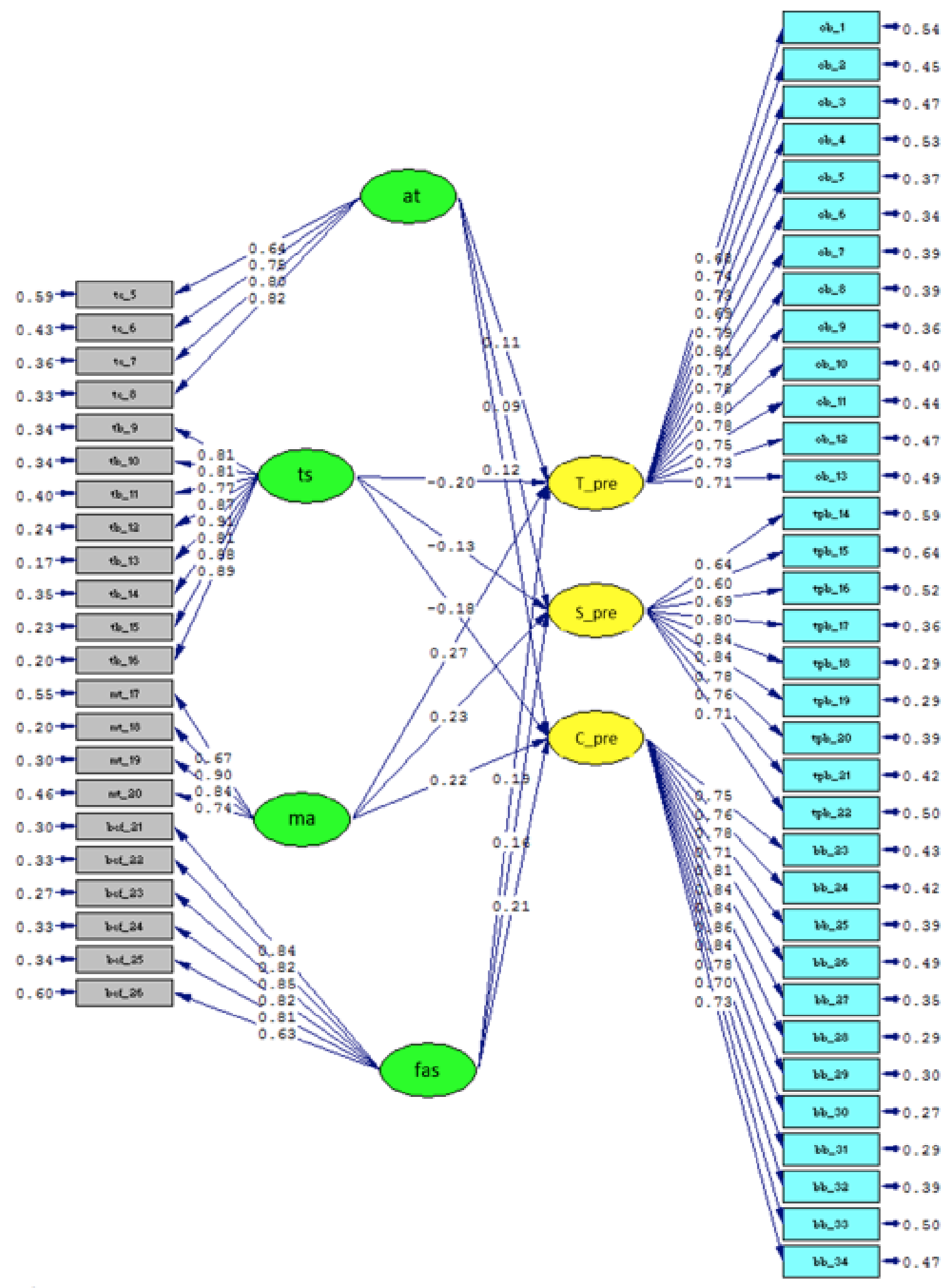

Chi-Square $=6522.31, \mathrm{df}=1466, \mathrm{p}$-value $=0.00000$, RMSEA $=0.070$

Figure 4. The effect of e-presence and expectation levels of the students on the students' presence levels

Table 5 demonstrates the effect of e-Presence and Expectation on Col Presences. "e-Presence and Expectation Dimensions" explain $16 \%$ of teaching presence, $11 \%$ of social presence and $19 \%$ of cognitive presence. Other dimensions, except for technical skills, have a small but significant effect on all Col Presences. In this context, students with high technical skills have higher presence perceptions than those with low technical skills. 
Table 5. The Effects e-Presence and Expectation on Col Presences

\begin{tabular}{|c|c|c|c|c|c|c|c|c|c|}
\hline \multirow{2}{*}{$\begin{array}{l}\text { e-Presence } \\
\text { and Expectation } \\
\text { Dimensions }\end{array}$} & \multicolumn{3}{|c|}{ Teaching Presence } & \multicolumn{3}{|c|}{ Social Presence } & \multicolumn{3}{|c|}{ Cognitive Presence } \\
\hline & Beta & $\mathrm{t}$ & R2 & Beta & $\mathrm{t}$ & $\mathrm{R} 2$ & Beta & $\mathrm{t}$ & $\mathrm{R} 2$ \\
\hline Access to technology & 0,11 & 1,77 & 0,01 & 0,12 & 1,42 & 0,01 & 0,09 & 1,95 & 0,01 \\
\hline The technical skills & $-0,20$ & $-3,53$ & 0,04 & $-0,13$ & $-2,33$ & 0,02 & $-0,18$ & $-3,24$ & 0,03 \\
\hline Motivation and attitudes & 0,27 & 4,79 & 0,07 & 0,23 & 4,05 & 0,05 & 0,33 & 3,97 & 0,11 \\
\hline $\begin{array}{l}\text { The factors affecting the } \\
\text { success }\end{array}$ & 0,19 & 3,51 & 0,04 & 0,16 & 2,86 & 0,03 & 0,21 & 3,78 & 0,04 \\
\hline Total Variance & & & 0,16 & & & 0,11 & & & 0,19 \\
\hline
\end{tabular}

\section{Effect of the Levels of Cognitive, Social, and Teaching Presence of the Students on Student Satisfaction}

In order to find answers to the fifth research question, the fit statistics of the structural equation model of this study were analyzed. It can be stated that the fit of the model was at a good level (NNFI=0.98, CFI $=0.99$, $\mathrm{NFI}=0.98$, RMSEA $=0.078$ ).

The structural equation model demonstrated that the effect size of the perception levels of the students' community of inquiry on student satisfaction was high. Hence, the increased perception levels of the students' community of inquiry may also increase their satisfaction levels in the dimensions of communication and usability, teaching process, learning content, interaction, and evaluation in the online course. Figure 5 shows the effect sizes for the sub-dimensions $\left(\mathrm{t}_{\text {col }>\mathrm{cu}}=22.52, \beta_{\text {col }>\mathrm{cu}}=0.88, \mathrm{t}_{\text {col }->\mathrm{tp}}=22.75, \beta_{\text {col }>\mathrm{tp}}=0.97, \mathrm{t}_{\text {col }-}\right.$ $\left.>\mathrm{tc}=26.83, \beta_{\text {col- }>\mathrm{tc}}=0.89, \mathrm{t}_{\mathrm{col}-\mathrm{ie}}=23.94, \beta_{\text {col } \rightarrow \mathrm{ie}}=0.90\right)($ see Figure. 5).

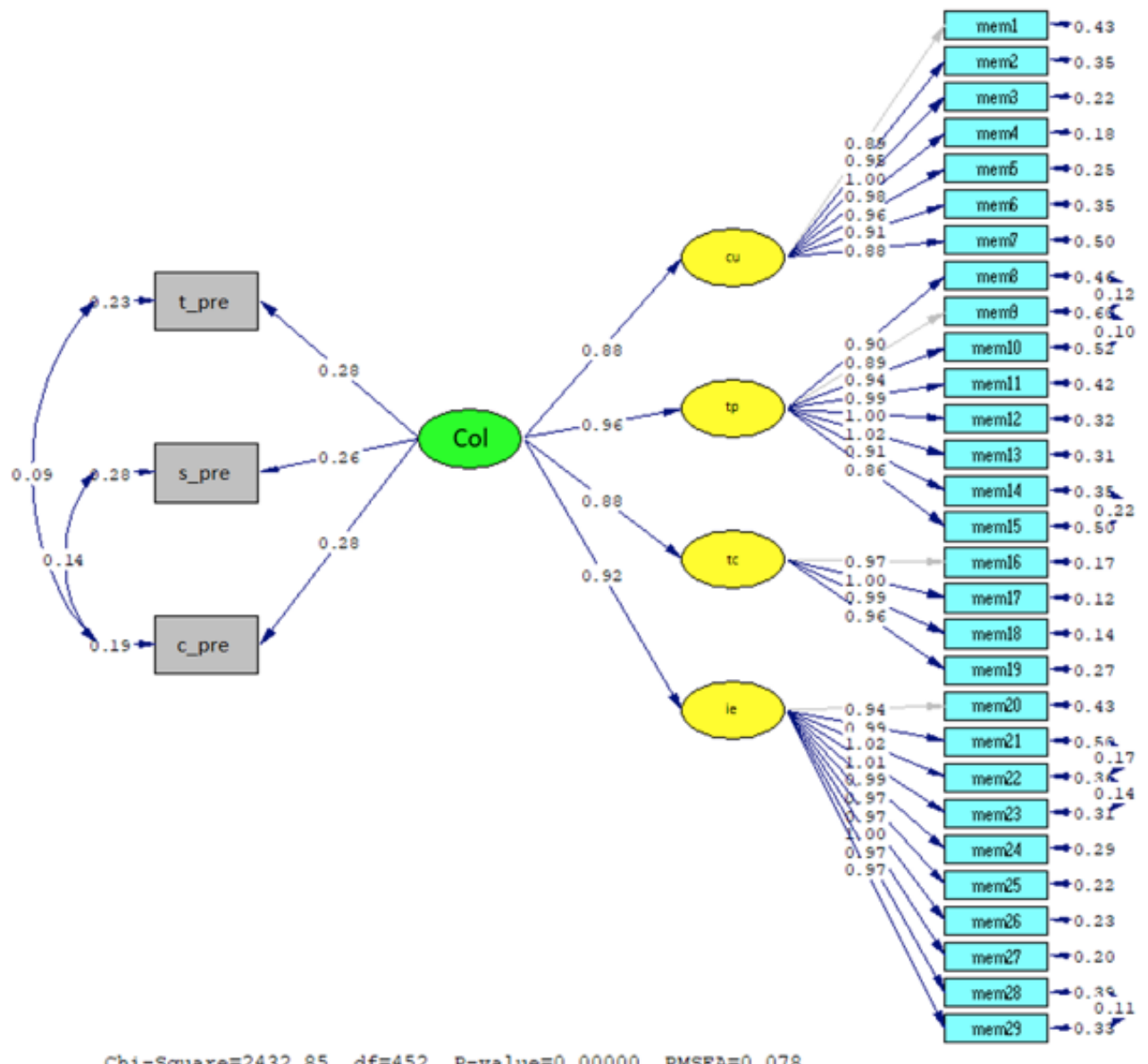

Figure 5. The effect of the presence levels of the students on student satisfaction levels 


\section{DISCUSSIONS}

Firstly, the online courses, which were evaluated in this study, were considered as efficient in creating a community of inquiry and promoting students' critical thinking. However, given the average scores, the courses should be improved. Although the average scores of the students' presence levels were closer to "I agree" $\left(X_{t \_p r e}=2,91, X_{\text {s_pre }}=2,98, X_{\text {c_pre }}=2,96\right)$, considering the courses evaluated in this study, there may be some controversial issues concerning the design of the online courses from the viewpoint of both instructors and instructional designers as well as of the institution.

First, it was found that teaching presence and social presence have a significant positive effect on cognitive presence $\left(\beta_{\text {teaching }}=0,38 ; \beta_{\text {social }}=0,56\right)$. Therefore, it can be stated that the impact of social presence is higher for cognitive presence in an online learning environment. In this context, a parallel result was obtained by Kovanovic, Gasevic, Joksimovic, Hatala, and Adesope (2015). They found that the use of different technology profiles (task-focused, content-focused, discussion-focused, social, high-active by the students in online environments) has a high effect size in terms of cognitive presence $(\beta=0.54)$, which leads to significant differences. Moreover, socially-focused intensive users were found to have higher cognitive presence than other profiles (Kovanovic et al., 2015). Therefore, diversification of learning pathways, including more social interactions for students, can be beneficial for the perception of a community of inquiry. For example, it was reported that the interactions concerning social presence were limited in online environments. For that reason, vision and design interventions should be developed to enable the integration of social networking sites such as Facebook, Instagram and Twitter, and online learning environments for education/learning (AlBalushi \& Al-Abdali, 2015; Ozturk, 2015). Moreover, in this study, social presence and teaching presence explained \%45,8 of cognitive presence at a lower rate than the literature. Gutierrez-Santiuste et al. (2015) found that these variables explained $81 \%$ of cognitive presence. However, it was found that the tools used in the course (e.g. chat, forum mail) affect this rate. For example, when tools were used together (forum, chat, and mail), this rate was $\% 81$. When the only chat was used, this rate was $\% 63$. When the only forum was used, this rate was $\% 79$. Therefore, the structure of courses in this study found may be a reason for the low rate $(45.8 \%)$. For example, the forums in the online learning environment where the research is conducted (e.g. student affairs, technical support) are used for support services beyond learning activities. Since the lessons are carried out mainly with live-lessons, the learning experiences may not have created an opportunity for the adequate development of social and teaching presence. On the other hand, Akyol et al. (2011) found differences in the three presences in short- and long-term courses. Similarly, when the changes by weeks in social and cognitive presence are examined in Rolim et al.'s research findings, it is seen that the dimensions related to social presence are more affected by time (Rolim, Ferreira, Lins, \& Gasevic, 2019, p.61). Therefore, the predictive power of social presence on cognitive presence may differ depending on the time when the Community of Inquiry perception is measured.

In this study, the community of inquiry did not vary significantly depending on age, gender, martial $\left(\mathrm{t}_{\text {age }}=1.01, \mathrm{t}_{\text {gender }}=1.07, \mathrm{t}_{\text {martial }}=0.08\right)$. In this case, maybe, it can be stated that the distance education courses evaluated in this study are provided with quality standards that meet the needs of students with different demographic characteristics (e.g. age). However, if such a situation had occurred, it would be expected that the students' average perception of presences and the relations of presences (e.g. effect of social and teaching on cognitive) would be higher. Therefore, age and community of Inquiry relationships are still open to discussion. In the current study, it can be said that there is low linear relationship between age and the Community of Inquiry since age is considered as a continuous variable. Akyol et al. (2010), while examining the effect of epistemological orientation (objectivist, constructivist) on the perception of community of inquiry, interestingly, found that in the data of learners between the ages of 18-22 and 48-62, regardless of epistemological orientation, teaching and cognitive presences were loaded in the same dimension. At the same time, they found that in the age group of 23-37 (regardless of objectivist or constructivist) and 38-47 (when epistemological orientation is constructivist), each presence dimension was loaded separately, and in the 38-47 age group (when epistemological orientation is constructivist), teaching and cognitive presence were loaded in the same dimension. Accordingly, the relationship between age and the community of inquiry is likely to be affected by the teaching/learning approaches adopted in the courses.

In the current study, the community of inquiry varied significantly depending on program and profession status (tprogram $=-2.41$, tprofession $=2.25$ ), but the effect size was very small (tprofession $=0.09^{*}$, tprogram $=$ 
$-0.12^{*}$ ). The registered programs do not have a similar feature according to the structure (e.g. "pure or applied" and "hard" or "soft"). For example, (C) Computer Programming is more application-based and hard discipline than (F) Divinity. However, the average scores of both the social and teaching presences of the two programs $(\mathrm{C}$ and $\mathrm{F})$ are close to each other $\left(\mathrm{C}_{\mathrm{SP}}=2.90 ; \mathrm{F}_{\mathrm{SP}}=2.93 ; \mathrm{C}_{\mathrm{TP}}=2.93 ; \mathrm{F}_{\mathrm{TP}}=2.83\right)$. Considering the researches (Arbaugh et al., 2010; Arbaugh, 2013; Vo, Zhu \& Diep, 2020) in the literature, the difference can be expected to be greater. Learners' presences (teaching, social, and cognitive) differed in terms of pure or applied disciplines (Arbaugh et al., 2010) and hard or soft discipline (Arbaugh, 2013). Vo et al. (2020) found that learners in soft disciplines (such as social sciences, political science) obtain higher grades than peers in hard disciplines. Therefore, even if the effect of the registered programs on the Community of Inquiry is small, programs' features should be investigated in more depth. For example, are courses' goals and expectations announced in all programs? How are the material qualities? What types of learning activities are organized? In terms of profession, learners who have a profession can be expected to have high selfconfidence in terms of forming the Community of Inquiry as they have work experience. Also, they may have made more use opportunities of online learning (e.g. flexible time). In this context, the expectations of the learners who have a profession may have been met more due to the nature of distance education (flexible place and flexible time).

Since e-presence and expectation level had a low effect size, the perception of the community of inquiry may be interpreted as "the students enrolled in the program had very similar characteristics in terms of their perception on technical skills, access to technology, motivation and attitude, or the factors affecting success." However, such interpretation may also contain some contradictions within itself. When the age range of the students (17-54) was evaluated, there might have been different student profiles in terms of technical skills, as well as the factors affecting success, motivation and attitude. In this regard, a more reasonable interpretation may be that "online courses make it easier for students to access the system and use it, and meet the students' needs in terms of student motivation and attitude or the factors affecting success." But, access to technology, motivation and attitudes, factors affecting success, positively affect the presences of Col, while technical skill level adversely affects. Normally, a reverse finding may be expected given that those with high technical skills may use the system's facilities more actively. But, students with high technical skills have higher presence perceptions than those with low technical skills. In this context, it could be claimed that online courses may be inadequate to meet the expectations of students with high technical skills.

Lastly, the structural equation model demonstrated that the effect size of the perception levels of community of inquiry of the students on student satisfaction was high. In order to ensure the consistency of the study, the impact of community of inquiry on students' satisfaction level can be analyzed, which, in turn, will enable us to make some predictions. As expected in this study and other similar studies, the students' presence perceptions predict high satisfaction levels (Alaulamie, 2014; Giannousi \& Kioumourtzoglou, 2016; Gutierrez-Santiuste, 2016; Horzum, 2015; Joo, Lim, \& Kim, 2011).

\section{CONCLUSIONS}

This study aims to evaluate the educational effectiveness of online courses based on the Community of Inquiry model and to make suggestions for the improvement of these courses. To this end, this study revealed the differences in demographic characteristics of the participants and their e-presence and expectation levels in online learning, and analyzed the impact of demographic characteristics and e-presence and expectation on cognitive, social, and teaching presence. Moreover, to eliminate the concerns on the model to be used for the evaluation of educational effectiveness, the impact of the students' perception levels of a community of inquiry on their satisfaction levels was also examined in the study.

In the evaluated courses, teachers give live lessons with their students every week and the records of the lessons can be watched by the students later. Such a course structure includes the components that must be included in the courses of Distance Education programs as required by the "Procedures and Principles Regarding Distance Education in Higher Education Institutions" (Council of Higher Education, n.d.). Also, the system allows teachers to design various activities (discussion, assessment, content transfer) for learners in terms of asynchronous interaction. The findings of the current study indicated that the online courses examined in this study were found to be sufficient by students in forming a community of inquiry. However, the average scores of their presence levels and predictive relationship between the presence of Community 
of Inquiry and other variables revealed that certain aspects of the courses should be improved. The current study can be concluded that there is a need for more social, more active, and engaging learning activities that enable students to think critically and in an online environment. Thus, an environment can be prepared for deeper learning by increasing the social, cognitive and instructional presence for the evaluated lessons. In this context, practitioners responsible for structuring the course should be aware of the use of tools that will increase their teaching, social, and cognitive presence perception in the online learning environment. Units responsible for Distance Education (Faculty, Vocational High School, or Distance Education Center) should create sample lesson designs showing the use of these tools in line with the learner's needs and set quality standards for the Community of inquiry. The more the Community of Inquiry synergy can be increased in the courses, the more students' satisfaction or academic success will increase.

The research sheds light on future research in four aspects. First, while looking effectiveness of online courses, learners' characteristics and disciplinary differences could not provide insight into the design of courses. The relationships between the age variable and the Community of Inquiry are still a subject that needs to be investigated according to both instructional approaches and the way the age variable is handled. In this study, a linear effect of age on the Community of Inquiry was not observed. However, there are findings in the literature that these relationships may not be linear (Akyol et al., 2010). In this context, future researches may test the Community of Inquiry relationships by considering the age variable categorically. Second, it is not answered why students with high technical skills have lower the Community of Inquiry. An in-depth study of the expectations of the students with high technical skills from online courses may be beneficial. Third, if the registered programs actually have an effect on the the Community of Inquiry, the effects programs' features on the Community of Inquiry perceptions can be investigated further by separating the programs by types of disciplines (hard or soft, pure or applied) or by considering the course structure (clear goals and expectation, material quality, learning activities) in the programs. Lastly, further studies may examine the impact of the students' presence perceptions on their academic success, and the type and frequency of activities in online environments they used or prefer.

The findings of this study should be evaluated considering the context of distance education. The educational effects of the levels of teaching, social, and cognitive presences vary depending on the situation and context (e.g. blended, face to face, or only online) (Szeto, 2015). In the context of blended learning, the advantages of face-to-face interaction can be useful in creating a community of Inquiry synergy online. In this case, learners can benefit from this advantage at different rates depending on demographic variables (e.g. age, gender). For example, the social presence of younger learners may be higher, and the teaching presence of the older ones. However, due to some limitations of the online environment (e.g. not using a facilitating tool such as a forum in the lesson), the effect of demographic variables may not be observed. The current study presents a context featuring individual responsibility for only online environments. Therefore, it is possible that there may be different conclusions on the presence components when it comes to mixed (online, blended, or face-to-face) learning schemes with higher instructive control.

\section{BIODATA and CONTACT ADDRESSES of AUTHORS}

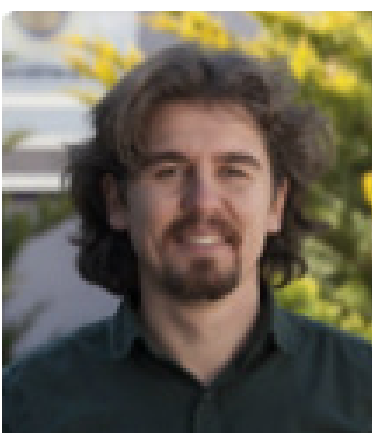

Dr. Denizer YILDIRIM has been working as Instructional Designer at Faculty of Open and Distance Education, Ankara University for ten years. Dr. Yildirim gained his Ph.D. in Department of Computer Education and Instructional Technology, Hacettepe University, in October 2018. His academic interest areas are learning analytics, educational data mining, technology integration in education, distance education, e-learning. He has journal articles published in international indexes, international and national book chapters, and papers submitted to international meetings. 


\section{Denizer YILDIRIM}

Faculty of Open and Distance Education

Address: Ankara University, Besevler 10. Year Campus, 06100, Yenimahalle, Ankara, Turkey.

Phone: +90 312600141/2431

E-mail: dyildirim@ankara.edu.tr

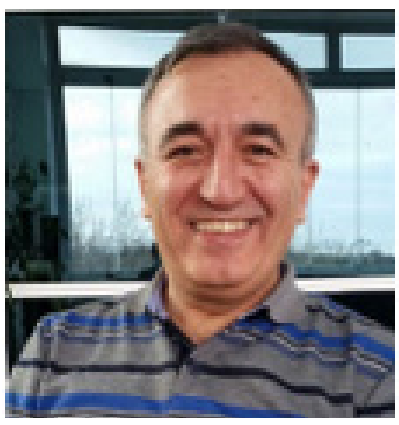

Dr. Suleyman Sadi SEFEROGLU is professor of instructional technology at the Department of Computer Education and Instructional Technology of Faculty of Education at Hacettepe University in Ankara, Turkey. During his undergraduate he received degrees in Radio-TV and Educational Sciences, in Ankara, Turkey. He completed his graduate studies at Columbia University in New York. At National Center for Restructuring Education, Schools, and Teaching (NCREST) of Teachers College Columbia University, he worked as a research associate in a part of his post doctorate. Dr. Seferoglu authored a book titled "Instructional Technology and Material Design", and co-authored several books on the issues related to the use of technology in education. e-Learning, technology policies, instructional material design-development, teacher education, professional development, pre-service and in-service teacher training, cyberbullying, Internet risks and threats, social media, children and media are his professional interests.

\section{Suleyman Sadi SEFEROGLU}

Department of Computer Education and Instructional Technology (CEIT)

Address: Hacettepe University, Faculty of Education, 06800, Beytepe, Ankara, Turkey.

Phone: +90(312)297-7176

E-mail: sadi@hacettepe.edu.tr

\section{REFERENCES}

Akyol, Z., Ice, P., Garrison, R., \& Mitchell, R. (2010). The relationship between course socio-epistemological orientations and student perceptions of community of inquiry. The Internet and Higher Education, 13(1-2), 66-68. Doi:10.1016/j.iheduc.2009.12.002

Akyol, Z., Vaughan, N., \& Garrison, D. R. (2011). The impact of course duration on the development of a community of inquiry. Interactive Learning Environments, 19(3), 231-246. Doi:10.1080/10494820902809147

Alaulamie, L. A. (2014). Teaching presence, social presence, and cognitive presence as predictors of students' satisfaction in an online program at a Saudi University. Unpublished Doctoral dissertation, Ohio University, USA.

Al-Balushi, S. M., \& Al-Abdali, N. S. (2015). Using a Moodle-based professional development program to train science teachers to teach for creativity and its effectiveness on their teaching practices. Journal of Science Education and Technology, 24(4), 461-475. Doi:10.1007/s10956-014-9530-8

Anderson, T. (2003). Getting the mix right again: An updated and theoretical rationale for interaction. The International Review of Research in Open and Distributed Learning, 4(2). Doi:10.19173/irrodl. v4i2.149

Anderson, T. (2008). Towards a theory of online learning. Theory and practice of online learning, 2, 15-44. Athabasca University, Canada.

Arbaugh, J. B. (2013). Does academic discipline moderate CoI-course outcomes relationships in online MBA courses? The Internet and Higher Education, 17, 16-28. Doi: 10.1016/j.iheduc.2012.10.002

Arbaugh, J. B., Bangert, A., \& Cleveland-Innes, M. (2010). Subject matter effects and community of inquiry (CoI) framework: An exploratory study. The internet and higher education, 13(1-2), 37-44. Doi:10.1016/j.iheduc.2009.10.006 
Choy, J. L. F., \& Quek, C. L. (2016). Modelling relationships between students' academic achievement and community of inquiry in an online learning environment for a blended course. Australasian Journal of Educational Technology, 32(4). Doi:10.14742/ajet.2500

Council of Higher Education, (n.d.). Procedures and Principles Regarding Distance Education In Higher Education Institutions [Yuksekogretim Kurumlarinda Uzaktan Ogretime Iliskin Usul ve Esaslar]. Retrieved January 30, 2020 from http://t.ly/QfLG

Crowther, M. S., Keller, C. C., \& Waddoups, G. L. (2004). Improving the quality and effectiveness of computer-mediated instruction through usability evaluations. British Journal of Educational Technology, 35(3), 289-303. Doi:10.1111/j.0007-1013.2004.00390.x

Decker, J., \& Beltran, V. (2016). Students' Sense of Belonging in Online Classes: Does Age Matter? International Journal of Online Pedagogy and Course Design (IJOPCD), 6(3), 14-25. IGI Global. Retrieved January 16, 2020 from https://www.learntechlib.org/p/185696/.

Dempsey, P. R., \& Zhang, J. (2019). Re-Examining the Construct Validity and Causal Relationships of Teaching, Cognitive, and Social Presence in Community of Inquiry Framework. Online Learning, 23(1), 62-79. Doi:10.24059/olj.v23i1.1419

Duffin, E. (2019). E-learning and digital education - Statistics \& Facts. Retrieved December 22, 2019, from https://www.statista.com/topics/3115/e-learning-and-digital-education/

Eom, S. B., \& Ashill, N. (2016). The determinants of students' perceived learning outcomes and satisfaction in university online education: An update. Decision Sciences Journal of Innovative Education, 14(2), 185-215. Doi:10.1111/j.1540-4609.2006.00114.x

Garrison, D. R. (2011). E-learning in the 21st century: A framework for research and practice. Routledge.

Garrison, D. R. (2016). E-learning in the 21st century: A community of inquiry framework for research and practice. Routledge.

Garrison, D. R., Anderson, T., \& Archer, W. (2000). Critical inquiry in a text-based environment: Computer conferencing in higher education. The Internet and Higher Education, 2(2), 87-105. Doi:10.1016/ S1096-7516(00)00016-6

Garrison, D. R., Cleveland-Innes, M., \& Fung, T.S. (2010). Exploring causal relationships among teaching, cognitive and social presence: Student perceptions of community of inquiry framework. Internet and Higher Education, 13(1-2), 31-36. Doi: 10.1016/j.iheduc.2009.10.002

Giannousi, M., \& Kioumourtzoglou, E. (2016). Cognitive, social, and teaching presence as predictors of students' satisfaction in distance learning. Mediterranean Journal of Social Sciences, 7(2), 439-447. Doi: $10.5901 / \mathrm{mjss} .2016 . v 7 \mathrm{n} 2 \mathrm{~s} 1 \mathrm{p} 439$

Gutierrez-Santiuste, E., Rodriguez-Sabiote, C., \& Gallego-Arrufat, M. J. (2015). Cognitive presence through social and teaching presence in communities of inquiry: A correlational-predictive study. Australasian Journal of Educational Technology, 31(3), 349-362. Doi:10.14742/ajet.1666

Gulbahar, Y. (2012). Study of developing scales for assessment of the levels of readiness and satisfaction of participants in e-learning environments. Ankara University Journal of Faculty of Educational Sciences, 45(2), 119-137. Doi: 10.1501/Egifak_0000001256

Heilporn, G., \& Lakhal, S. (2020). Investigating the reliability and validity of community of inquiry framework: An analysis of categories within each presence. Computers \& Education, 145, 103712. Doi:10.1016/j.compedu.2019.103712

Hooper, D., Coughlan, J., \& Mullen, M. R. (2008). Structural equation modelling: Guidelines for determining model fit. Electronic journal of business research methods, 6(1), 53-60. ISSN 1477-7029 Retrieved January 16, 2020 from http://mural.maynoothuniversity.ie/6596/1/JC-Structural-Equation.pdf

Horzum, M. B. (2015). Online learning students' perceptions of community of inquiry based on learning outcomes and demographic variables. Croatian Journal of Education, 17(2), 535-567. Doi: 10.15516/cje.v17i2.607 
Hu, L. T., \& Bentler, P. M. (1999). Cutoff criteria for fit indexes in covariance structure analysis: Conventional criteria versus new alternatives. Structural Equation Modeling: A Multidisciplinary Journal, 6(1), 1-55. Doi: 10.1080/10705519909540118

Hung, M. L., Chou, C., Chen, C. H., \& Own, Z. Y. (2010). Learner readiness for online learning: Scale development and student perceptions. Computers \& Education, 55(3), 1080-1090. Doi:10.1016/j. compedu.2010.05.004

Ilgaz, H., \& Gulbahar, Y. (2015). A snapshot of online learners: e-Readiness, e-Satisfaction and expectations. The International Review of Research in Open and Distributed Learning, 16(2). Doi:10.19173/ irrodl.v16i2.2117

INACOL (2011). National standards for quality online teaching. iNACOL - International Association for K-12 Online Learning. Retrieved December 12, 2019 from http://www.inacol.org/wp-content/ uploads/2015/02/national-standards-for-quality-online-teaching-v2.pdf

INACOL (2012). Creating student learning performance. Metrics and quality assurance for online schools. iNACOL - International Association for K-12 Online Learning. Retrieved December 12, 2019 from http://www.inacol.org/wp-content/uploads/2015/02/iNACOL_Quality_Metrics.pdf

Johnson, L., Adams Becker, S., Estrada, V., Freeman, A. (2014). NMC Horizon Report: 2014 Higher Education Edition. Austin, Texas: The New Media Consortium.

Joo, Y. J., Lim, K. Y., \& Kim, E. K. (2011). Online university students' satisfaction and persistence: Examining perceived level of presence, usefulness and ease of use as predictors in a structural model. Computers \& Education, 57(2), 1654-1664. Doi:10.1016/j.compedu.2011.02.008

Kanuka, H., \& Garrison, D. (2004). Cognitive presence in online learning. Journal of Computing in Higher Education, 15(2), 30-49. Doi:10.1007/BF02940928

Kovanovic, V., Gasevic, D., Joksimovic, S., Hatala, M., \& Adesope, O. (2015). Analytics of communities of inquiry: Effects of learning technology use on cognitive presence in asynchronous online discussions. The Internet and Higher Education, 27, 74-89. Doi: 10.1016/j.iheduc.2015.06.002

Kucuk, S., \& Richardson, J. C. (2019). A structural equation model of predictors of online learners' engagement and satisfaction. Online Learning, 23(2), 196-216. Doi:10.24059/olj.v23i2.1455

Lambert, J. L., \& Fisher, J. L. (2013). Community of inquiry framework: Establishing community in an online course. Journal of Interactive Online Learning, 12(1), 1-16. Retrieved December 12, 2019 from https://www.ncolr.org/jiol/issues/pdf/12.1.1.pdf

McDonald, R. P., \& Ho, M. H. R. (2002). Principles and practice in reporting structural equation analyses. Psychological methods, 7(1), 64. Doi:10.1037/1082-989x.7.1.64

Moreira, J., Ferreira, A., \& Almeida, A. (2013). Comparing communities of inquiry of Portuguese higher education students: One for all or one for each?. Open Praxis, 5(2), 165-178. Doi:

Ozturk, E. (2012). Arastirma toplulugu olceginin Turkceye uyarlanmasi: Gecerlik ve guvenirlik calismasi [An Adaptation of the Community of Inquiry Index: The Study of Validity and Reliability]. Ilkogretim Online, 11(2). Retrieved January 15, 2020 from https://toad.halileksi.net/sites/default/files/pdf/ arastirma-toplulugu-olcegi-toad.pdf

Ozturk, E. (2015). Facebook as a new community of inquiry environment: An investigation in terms of academic achievement and motivation. Journal of Baltic Science Education, 14(1). Retrieved January 15, 2020 from http://oaji.net/articles/2016/987-1462907938.pdf

Ragowsky, A., Somers, T. M., \& Adams, D. A. (2005). Assessing the value provided by ERP applications through organizational activities. Communications of the Association for Information Systems, 16(1), 18. Doi: $10.17705 / 1$ cais. 01618

Rockinson-Szapkiw, A. J., Wendt, J., Wighting, M., \& Nisbet, D. (2016). The Predictive Relationship Among the Community of Inquiry Framework, Perceived Learning and Online, and Graduate Students' Course Grades in Online Synchronous and Asynchronous Courses. International Review of Research in Open and Distributed Learning, 17(3). Doi:10.19173/irrodl.v17i3.2203 
Rolim, V., Ferreira, R., Lins, R. D., \& Gasevic, D. (2019). A network-based analytic approach to uncovering the relationship between social and cognitive presences in communities of inquiry. The Internet and Higher Education, 42, 53-65. Doi: 10.1016/j.iheduc.2019.05.001

Rubin, B., Fernandes, R., \& Avgerinou, M. D. (2013). The effects of technology on community of inquiry and satisfaction with online courses. The Internet and Higher Education, 17, 48-57. Doi: 10.1016/j. iheduc.2012.09.006

Seaman, J. E., Allen, I. E., \& Seaman, J. (2018). Grade Increase: Tracking Distance Education in the United States. Babson Survey Research Group.

Shea, P., \& Bidjerano, T. (2009). Community of inquiry as a theoretical framework to foster "epistemic engagement" and "cognitive presence" in online education. Computers \& Education, 52(3), 543553. Doi: 10.1016/j.compedu.2008.10.007

Shea, P., \& Bidjerano, T. (2012). Learning presence as a moderator in community of inquiry model. Computers \& Education, 59(2), 316-326. Doi:10.1016/j.compedu.2012.01.011

Siemens, G., Gasevic, D., \& Dawson, S. (2015). Preparing for the digital university: A review of the history and current state of distance, blended, and online learning. Arlington: Link Research Lab.

Simsek, O. F. (2007). Yapisal esitlik modellemesine giris: Temel ilkeler ve LISREL uygulamalari [Introduction to structural equation modeling: Basic principles and LISREL applications]. Ankara: Ekinoks Yayincilik.

Statista Research Department. (2017, March 23). Global student online course usage rate 2015 Published by Statista Research Department, Retrieved December 22, 2019 from https://www.statista.com/ statistics/548112/online-course-student-access-worldwide/

Stenbom, S. (2018). A systematic review of the Community of Inquiry survey. The Internet and Higher Education, 39, 22-32. Doi:10.1016/j.iheduc.2018.06.001

Swan, K., Day, S. L., Bogle, L. R., \& Matthews, D. B. (2014). A collaborative, design-based approach to improving an online program. The Internet and Higher Education, 21, 74-81. Doi:10.1016/j. iheduc.2013.10.006

Szeto, E. (2015). Community of Inquiry as an instructional approach: What effects of teaching, social and cognitive presences are there in blended synchronous learning and teaching? Computers \& Education, 81, 191-201. Doi: 10.1016/j.compedu.2014.10.015

Simsek, N. (2012). Quality indicators in distant education and the assessment of technology-based distant education according to these indicators. Journal of Educational Sciences \& Practices, 11(21). Retrieved December 22, 2019 from http://ebuline.com/pdfs/21Sayi/EBU21_1.pdf

Vo, M. H., Zhu, C., \& Diep, A. N. (2020). Students' performance in blended learning: Disciplinary difference and instructional design factors. Journal of Computers in Education, 1-24. Doi: 10.1007/ s40692-020-00164-7

Yeh, Y.-C. , Kwok, O.-M. , Chien, H.-Y. , Sweany, N. W. , Baek, E. , \& McIntosh, W. A. (2019). How college students' achievement goal orientations predict their expected online learning outcome: The mediation roles of self-regulated learning strategies and supportive online learning behaviors. Online Learning , 23(4), 23-41. Doi:10.24059/olj.v23i4.2076

Yukselturk, E., \& Yildirim, Z. (2008). Investigation of interaction, online support, course structure and flexibility as the contributing factors to students' satisfaction in an online certificate program. Educational Technology \& Society, 11(4), 51-65. 